引用格式: 张轩畅, 刘彦随, 李裕瑞, 等. 黄土丘陵沟壑区乡村生态产业化机理及其典型模式[J]. 资源科学, 2020, 42(7): 12751284. [Zhang X C, Liu Y S, Li Y R, et al. Mechanism and typical patterns of rural ecological industrialization in the Loess HillyGully region of China[J]. Resources Science, 2020, 42(7): 1275-1284.] DOI: 10.18402/resci.2020.07.05

\title{
黄土丘陵沟䜷区乡村生态产业化机理 及其典型模式
}

\author{
张轩畅 ${ }^{1,2,3}$, 刘彦随 ${ }^{1,2,3}$, 李裕瑞 ${ }^{1,2}$, 郭远智 ${ }^{1,2}$, 曹 智 1,2
}

(1. 中国科学院地理科学与资源研究所, 北京 $100101 ; 2$. 中国科学院区域可持续发展分析与模拟 重点实验室, 北京 100101 ; 3. 中国科学院大学资源与环境学院, 北京 100049)

\begin{abstract}
摘 要: 生态产业化是新时代推进生态建设与产业发展良性循环、促进乡村地域系统可持续发展的重要途 径。黄土丘陵沟壑区位于黄河中游地区, 作为黄土高原典型地貌单元, 其乡村生态环境脆弱、人地矛盾突出, 退耕 还林(草)工程后生态功能显著改善,但农业基础薄弱、水土约束增强、生产效益偏低等问题依旧突出,亟需推进生 态产业化提升乡村生产和生活功能。本文从生态资源价值增殖角度, 探讨了黄土丘陵沟餐区乡村生态产业化的内 在机理, 并结合延安市治沟造地工程后的典型实践, 提出了适合该区域发展的产业化模式及其可持续途径。结果 表明: 1)乡村生态产业化应遵循乡村地域系统演化规律、耦合机理以及价值转化原则,依托地理工程技术加快生态 资源培育, 建立生态产权管理制度实现生态资源资产化,通过资产集中流转、经营主体培育、产业要素融合等推进 生态资产资本化, 完善生态市场交易机制保障生态产品与服务市场化; (2)延安市部分乡村依托治沟造地工程实现 了生态资源培育, 探索了“资源变资产、资产变资本、资本变资金”的路径, 已初步形成了高效种养、休闲农业和多元 综合等生态产业化模式; (3)未来应注重地理工程成效管护、健全产权管理制度、发挥能人带动作用、吸纳社会力量 参与以及构建动态评价机制, 补齐产业化过程中的短板, 推进乡村生态、生产、生活的有机融合, 实现乡村产业兴 旺、生态宜居和生活富裕的振兴目标。
\end{abstract}

关键词: 生态产业化; 乡村地域系统;地理工程;乡村振兴;黄土丘陵沟壑区;延安市

DOI :10.18402/resci.2020.07.05

\section{1 引言}

改革开放以来, 城镇化和工业化快速发展深 刻影响着中国的城乡地域空间、产业结构和社会 关系 ${ }^{[1]}$ 。但传统发展模式过度追求生产规模、增长 速度与经济效益, 忽视生态环境保护与资源集约利 用, 导致生态退化、环境污染等问题突出。而随着 城乡居民收入和消费水平的提高, 人们对优美生态 环境的需求日益增长 ${ }^{[2]}$ 。为此, 中央提出加快推进 生态文明建设, 构建以产业生态化和生态产业化为 主体的生态经济体系。生态产业化是通过社会化
生产和市场化经营,提供更多优质生态产品和服 务, 推动生态要素向生产要素、资源禀赋向物质财 富转变的过程, 是新时代践行 “绿水青山就是金山 银山”理念的科学途径。

乡村是生态资源最为丰裕的地区, 但面临着生 态建设与产业发展的双重压力, 生态产业化为二者 的有机融合提供新思路 ${ }^{[3]}$ 。乡村生态产业化理念由 来已久,Anderson 等 ${ }^{[4]}$ 在 1991 年已提出市场运营能 够有效保护生态环境并创造经济利润。世界各国 在乡村转型发展过程中都探索了适合本国国情的

收稿日期: 2019-11-29, 修订日期: 2020-02-29

基金项目: 国家重点研发项目 (2017YFC0504701); 国家自然科学基金项目 (41931293; 41971220); 中国科学院战略性先导科技专项 (XDA23070300)。

作者简介: 张轩畅,男,山东莱芜人,博士生,研究方向为乡村地理与土地工程。E-mail: zhangxc.18b@igsnrr.ac.cn

通讯作者: 刘彦随, 男, 陕西绥德人, 研究员, 博士生导师, 研究方向为乡村地理学、城乡发展与土地利用。E-mail: liuys@igsnrr.ac.cn 
生态产业化模式 ${ }^{[5,6]}$, 德国、荷兰等国家通过生态整 治形成了以创意农业和乡村旅游为主体的多元功 能模式, 日本、韩国等国家基于产业融合构建起以 “六次产业化”为主体的资源集约模式。在生态文 明、精准扶贫和乡村振兴等战略推动下, 中国各地 区乡村也形成了各具特色的生态产业化模式, 如以 优势农业和生态旅游为主的安吉模式、以休闲农业 为主的红岩村模式等, 为乡村生态产业化提供了良 好范式 ${ }^{[7]}$ 。

基于生态经济学理论和典型实践, 相关学者深 人剖析生态资源、资产和资本的内涵、特征及其价 值转化规律 ${ }^{[2,8]}$, 提出引人社会力量参与生态建设, 运用市场手段开展生产经营, 实现生态资源价值增 殖是协调生态建设与产业发展矛盾的重要途径 ${ }^{[9,10]}$, 并提出生态经济化、生态资产资本化、特色生态经 济模式等与生态产业化相关理念 ${ }^{[2,11,12]}$ 。根据生态资 源形态演变和价值转化规律, 生态产业化过程被划 分为资源培育、资产转化、资本运营以及价值实现 等环节 ${ }^{[2,1]}$, 并以土地、水等资源为例解析了其实现 机理及效应 ${ }^{[13,14]}$ 。针对生态产业化各过程环节的关 键问题, 国内外研究提出研发生态保护技术 ${ }^{[12]}$ 、健全 产权管理制度 ${ }^{[10]}$ 、探索资本运营方式 ${ }^{[11]}$ 以及完善市 场交易机制 ${ }^{[15]}$ 等实现路径, 为乡村生态产业化机理 研究、路径探索和模式总结奠定理论基础。

黄土丘陵沟壑区地处黄河中游地区, 是黄土高 原典型的地貌单元之一, 总面积约 14 万 $\mathrm{km}^{2}$, 涉及陕 西、山西、内蒙古等 3 省 64 个县 (区)。该区域地表 破碎、生态脆弱、暴雨集中,长期以来滥伐、滥层、监 牧等不合理的人类活动造成严重的水土流失。同 时, 城乡分割的二元体制和重城轻乡的发展战略 下,乡村生产要素高速非农化、城市和工业污染向 农村排放, 以“乡村病”为主要特征的乡村衰败日趋 严峻, 是中国人地矛盾最为突出的地区之一 ${ }^{[5,16]}$ 。近 年来, 在退耕还林(草)工程的作用下, 区域植被覆 盖度大幅提高、生态环境明显改善、承载力显著提 升 ${ }^{[17,18]}$ 。但坡耕地的快速减少导致土地资源约束增 强, 局部地区出现 “缺地少粮” 问题。同时, 大部分 乡村经营主体薄弱、资金技术短缺、产业融合不足， 农业生产仍延续传统耕作方式, 玉米种植收益不足 700 元/亩 ${ }^{[19,20]}$, 影响着粮食安全和农户生计 ${ }^{[21]}$ 。区域
生态资源数量和质量的提升为乡村转型提供了后 发优势, 但因缺乏有效路径导致生态资源难以转化 为维持农民生计的资产和资本, 加之生态补偿不 足,农民生态保护积极性受挫,严重制约着乡村转

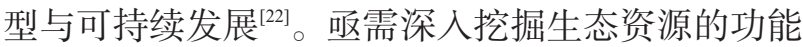
与价值, 探索生态建设与产业发展良性循环的生态 产业化路径 ${ }^{[23,24]}$, 推动乡村生态、生产和生活功能的 同步提升。

本文依据乡村地域系统、生态价值、地理工程 和科斯产权理论, 从生态资源价值增殖角度, 系统 剖析黄土丘陵沟壑区乡村生态产业化内在机理,并 结合延安市的典型实践提出适宜区域发展的产业 化模式及其可持续路径, 为协调生态建设、产业发 展和农民增收的关系, 实现产业兴旺、生态宜居和 生活富裕的目标, 推动乡村地域系统转型发展与城 乡融合提供参考。

\section{2 生态产业化理论基础}

乡村产业生态化与生态产业化是相辅相成的, 目标均为遵循生态演化和产业发展规律, 实现生态 环境保护与经济高质量发展的良性循环 ${ }^{[3]}$ 。但二者 的侧重点有所不同,产业生态化强调基于生态演化 规律对传统产业生产技术、过程进行改造升级, 解 决资源利用不足、环境污染的问题，在经济效益增 加的同时减少 “三废” (废水、废气、废渣) 排放 ${ }^{[25]}$; 生 态产业化注重采用社会化生产、市场化经营等方 式, 挖掘生态资源的价值功能, 培育适合乡村生态 保护与富民增收相协调的新业态, 解决生态建设制 约农民生计的问题, 实现绿水青山提质增效与乡村 转型振兴有机结合 ${ }^{[25,26]}$

乡村生态产业化是乡村生态资源作为生产要 素, 参与社会生产、分配、交换和消费, 实现价值增 殖的绿色产业模式。从乡村地域系统视角看, 生态 产业化的实质是通过乡村资源、环境、人文、经济等 子系统交互作用优化, 实现产业结构转型的过程, 但不同区域要素构成、耦合结构和演化过程差异显 著,因此在该过程中应着眼于系统地域分异、耦合 机理与演化规律, 确保生态资源开发强度与自然承 载力相适宜, 适度激发系统各要素活力实现乡村产 业转型 ${ }^{\left[{ }^{[}\right]}$。生态价值理论认为, 生态资源的稀缺性、 效用性使其能够与其他资源一样,通过“存在价值 
关系划分、社会化生产与市场化运作,整合经济系 统中农业、工业、服务业等要素,从而实现乡村地域 产业结构转型。根据生态资源的形态演化与价值 转化,生态产业化过程可划分为以下 4 个环节: (1)生 态资源培育, 即资源存在价值提升的环节; (2)生态 资源资产化, 即资源存在价值向资产使用价值转化 的环节; (3)生态资产资本化, 即资产使用价值转化 为资本要素价值, 再转化为生态产品与服务交换价 值的环节 ; (4)生态产品与服务市场化, 即交换价值 最终实现,并为资源培育提供资金的环节 (图 1)。 生态产业化的各过程环节是相辅相成、不可分割 的, 只有各环节有序开展才能有效激发生态资源活 力,形成生态溢出效应, 实现绿水青山提质增效。

\section{1 生态资源培育}

生态资源培育是依托地理工程技术,对退化或 不可持续的生态要素进行整治培育, 提升生态资源 数量、质量和功能的环节。针对当前黄土丘陵沟壑 区乡村存在的水土流失、耕地短缺、环境污损、土地 贫㾑等问题,应立足于区域水土保持的主导功能, 根据生态要素的演化规律及功能目标研发整治优 化技术, 通过扎实开展各类地理工程推动流域空间 重构,夯实生态产业化的资源基础。针对以上问题 开展的工程有: (1)稳步推进退耕还林 (草)工程, 根 据区域气候条件、生态承载力和植被适应性探索群 落优化技术,重点解决植被退化与水资源短缺的问 题; (2)科学推进治沟造地工程,利用增强型工程技 术体系对水毁沟道进行综合整治,协调水土要素耦 合关系,并通过高标准农田建设增加耕地数量 ${ }^{[32]}$; (3) 着力推进人居环境治理工程, 开展垃圾集中处理、 生活污水循环和旱则改造等工作,实现乡村景观环 境美化; (4)加快推进土壤复配工程, 基于土壤微观 结构选取红粘土作为天然改良剂,解决黄绵土 “三 跑” (跑水、跑土、跑肥) 问题, 并结合作物生长特性 进行不同比例复配, 营造健康稳定的土体, 提升耕 地质量与功能 ${ }^{[29]}$ 。

\section{2 生态资源资产化}

生态资源资产化是在政府引导、政策调控和技 术推动下, 建立乡村生态产权管理制度, 界定生态 资源产权归属与权责关系的环节。产权虚置与权 责不明是黄土丘陵沟壑区生态资源低效利用的根 


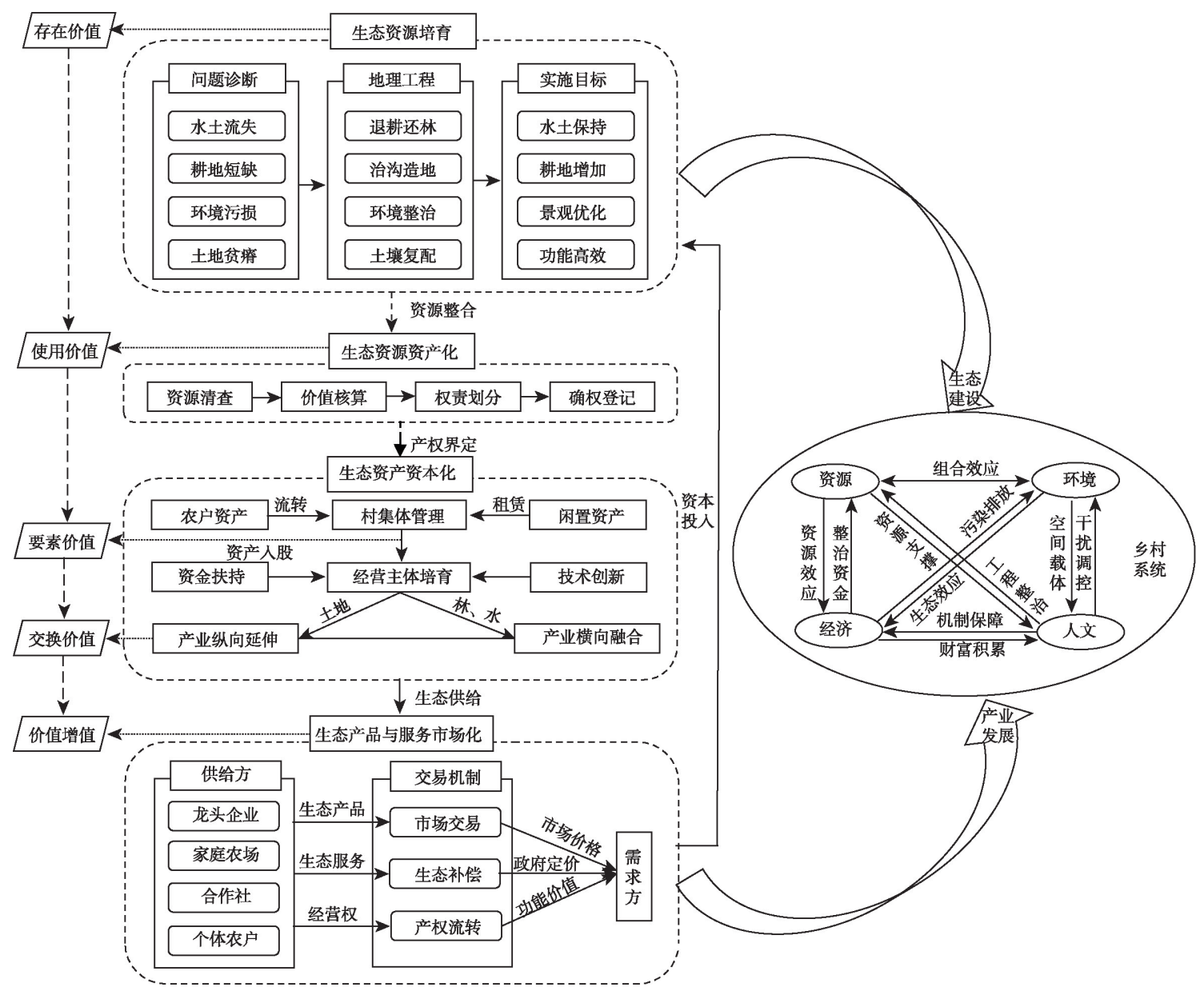

图 1 黄土丘陵沟壑区乡村生态产业化机理图

Figure 1 Mechanism of ecological industrialization in the Loess Hilly-Gully region

源 ${ }^{[33]}$ 。坚持生态资源国家或集体所有的原则, 县级 政府代行所有权,积极发挥监督管理作用。相关部 门应组织开展资源清查, 利用遥感监测技术, 并结 合统计填报、野外普查, 明确各类生态资源的数量、 质量和边界。基于现行自然资源统计核算体系, 根 据生态资源特征和交易需求,研发兼顾科学性、全 面性和可操作性的价值核算方法 ${ }^{[34]}$ 。制定生态资源 占用、处置和收益等主体及其权责关系界定准则， 开展确权、登记和颁证工作, 保障产权主体的合法 权益, 减少产权纠纷 ${ }^{[3,36]}$ 。村集体严把林(草)地产 权, 杜绝滥垦、滥伐、滥牧, 严禁违规开发行为。耕 地、园地、鱼塘等实行所有权、承包权和经营权“三 权分置”, 确保承包权长期稳定, 但对承包资格丧失 或资源长期闲置的资源及时调整, 并鼓励农户以多 种形式流转和出让经营权。土地整治新增耕地实 行“确权不确地”办法, 提高资产利用的灵活性。

\section{3 生态资产资本化}

生态资产资本化是政府引导农民进行资产集 中流转,通过资金扶持和技术创新培育新型经营主 体, 村集体以资产人股形式参与经营,融合乡村各 类产业要素生产提供生态产品和服务的环节 ${ }^{[2]}$ 。针 对黄土丘陵沟壑区生态资产分散经营导致利用效 率不足的问题, 应鼓励农民以出租、转包、托管、人 股等方式向村集体流转经营权,并以租赁方式回收 长期闲置的生态资产。营造良好的社会环境激励 能人返乡创业, 培育专业大户、家庭农场、专业合作 社等新型经营主体,破解老龄化、空心化引发的劳 动力要素短缺问题。加强银行、保险公司等金融机 构扶持力度,并广泛吸引社会资本以满足生产资金 需求。农业部门在推广先进生产技术的同时,积极 搭建与企业、高校、科研机构的合作平台,开展生态 资源集约利用技术研发与示范。根据经营主体发 
展意愿, 村集体以资产人股方式参与经营并按股 分红。

针对当前区域很多乡村延续单季玉米种植所 导致收益偏低的问题,新型经营主体应积极发挥主 导作用, 按照三产融合理念, 依托村域生态要素推 进各类产业要素整合 ${ }^{[21]}$ 。根据区域农牧交错和特色 林果的比较优势, 结合沟道立体农业布局, 充分利 用土地要素, 促使生态产业链纵向延伸。山塬苹 果、红杳、梨等园地开展精细化管理, 提高特色林果 的产量与品质; 鼓励有条件的乡村在台地兴建设施 农业, 种植草莓、西瓜以及反季蔬菜等经济作物; 通 过良种选育、土壤复配和精准耕作, 提高坝地玉米 等粮食作物产量, 并结合气候变暖趋势推广“一季 变两季” 的复种模式, 引进油菜、菌草等饲草作物促 进畜牧业发展。依托生物、水体、景观等生态要素 推进生态产业链横向拓展, 定期对林(草)地进行保 育、更新和林分调整, 营造垂钓池、采摘园、康养吧 等生态景观发展生态旅游业, 具有革命遗址的特色 村需注重保护传承发展红色旅游, 实现特色农产 品、民俗文化和生态旅游“捆绑式”经营。适度发挥 产业集聚效应,在区域内逐步形成“一乡一业”“一 村一品”的生态产业格局。

\section{4 生态产品与服务市场化}

生态产品与服务市场化是采用多元市场交易 机制实现其交换价值, 促使乡村生态要素与城市 资金要素的双向流通, 并为生态资源培育提供资 金的环节 ${ }^{[36]}$ 。长期以来, 中国生态市场体系不健全 制约着产权流转、有效补偿以及产品销售, 亟需充 分发挥市场配置的基础性作用, 建立健全生态市场 交易机制。政府应因地制宜构建生态资产流转机 制, 规范各类生态资产流转价格、准则与过程, 建立 流转信息平台、掌握区域内生态资产供需状况, 成 立相关服务机构、促进生态资产流转有序开展。生 态补偿由政府支付逐步向政府引导转变,依据生态 建设者成本、受益者获益以及生态服务价值明确补 偿标准, 黄河下游地区企业或单位以资源税、碳税、 排污费等形式承担跨区域生态补偿责任, 居民以旅 游门票等形式支付生态服务费用。挖掘本地生态 产品特色优势, 加快推进产品 “三品一标” 认证, 提 升产品品质、附加值和知名度。搭建市场交易信息
平台, 采用微信推送等形式及时通知农民。积极拓 展产品销售市场, 强化与龙头企业、商场超市和农 贸市场的合作,形成“基地农业”销售模式,充分利 用阿里、京东等电商平台, 打造 “互联网 + ” 销售模 式。在为资源整合和持续经营留存资金的同时,根 据产业发展实际采取股份分红、利润返还、工资收 人等形式实现农民增收。

\section{4 黄土丘陵沟壑区乡村生态产业化典 型模式}

乡村生态产业化注重生态建设与产业发展的 有机融合, 生态建设为产业发展夯实资源基础, 产 业发展为生态建设提供资金支持, 是新时代国家生 态功能区乡村可持续发展的重要途径。延安市地 处黄土丘陵沟壑水土保持生态功能区的核心区域, 近年来稳步推进退耕还林(草)工程,生态建设取得 了显著成效,并以中央投资 48.32 亿元支持治沟造 地土地整治重大工程为契机, 采用增强型工程技术 变废弃沟道为高标准农田,搭建起规模化、集约化、 园区化的生态产业基地。部分乡村结合自身区位 条件、资源禀赋和产业基础，通过明晰产权归属、培 育特色产业和加强市场运作探索了“资源变资产、 资产变资本、资本变资金”的路径,多种生态产业化 模式初步显现。本文依据乡村生态产业化实现机 理, 基于当前该区域乡村生态产业化的典型实践, 提炼出高效种养、休闲农业和多元综合 3 种生态产 业化模式, 探讨其中不足并提出进一步发展路径 (表 1), 为黄土丘陵沟壑区乡村产业转型发展提供 模式参考。

\section{1 高效种养模式}

高效种养模式是基于土地要素多功能性形成 的种植、加工、养殖和林果相结合的农业体系。延 长县 $\mathrm{D}$ 村原为国家级贫困村, 长期以来农民收人主 要依赖于沟道玉米和塬区林果,但种植收益偏低导 致村内 $81 \%$ 的青壮劳动力进城务工。2013 年,D村 实施治沟造地工程平整川坝地 960 亩,并完善交通、 水利和电力等基础设施。在新增耕地归村集体所 有的前提下, 分包到户、确权颁证, 并鼓励农民以人 股、托管和转让等形式将经营权流转给村集体。受 益于精准扶贫政策,政府投资 300 万元成立股份合 
表 1 黄土丘陵沟壑区生态产业化典型模式

Table 1 Typical patterns of ecological industrialization in the Loess Hilly-Gully region

\begin{tabular}{|c|c|c|c|c|c|}
\hline $\begin{array}{l}\text { 模式 } \\
\end{array}$ & 案例 & 基本概况 & 模式亮点 & 局限不足 & 改进路径 \\
\hline $\begin{array}{l}\text { 高效种 } \\
\text { 养模式 }\end{array}$ & $\begin{array}{l}\text { 延长县 } \\
\mathrm{D} \text { 村 }\end{array}$ & $\begin{array}{l}\text { (1)治沟造地工程平整土地; } \\
\text { (2)地确权到户明晰产权; } \\
\text { (3)基于“合作社+农户”体系发展“种 } \\
\text { 植+加工十养殖+林果”高效农业; } \\
\text { (4)饲料、菌肥、肉牛和林果销售增收。 }\end{array}$ & $\begin{array}{l}\text { (1)发挥土地多功能性; } \\
\text { (2)人股、托管、转让等 } \\
\text { 形式流转经营权; } \\
\text { (3)“借牛还牛”激发农民 } \\
\text { 热情。 }\end{array}$ & $\begin{array}{l}\text { 产品滞销导致资金短 } \\
\text { 缺, 制约经营规模扩 } \\
\text { 大。 }\end{array}$ & $\begin{array}{l}\text { (1)建立批发市场; } \\
\text { (2)拓展零售渠道; } \\
\text { (3)增大政策扶持、财政投 } \\
\text { 资和贷款优惠力度; } \\
\text { (4)拓宽融资渠道。 }\end{array}$ \\
\hline $\begin{array}{l}\text { 休闲农 } \\
\text { 业模式 }\end{array}$ & $\begin{array}{l}\text { 宝塔区 } \\
\mathrm{S} \text { 村 }\end{array}$ & $\begin{array}{l}\text { (1)退耕还林、治沟造地和土壤复配工 } \\
\text { 程整治生态要素; } \\
\text { (2)采取“确权不确地”产权管理方式, } \\
\text { 并集中闲置土地; } \\
\text { (3)通过 “政府+合作社+农户”体系发 } \\
\text { 展“种养结合+生态旅游”休闲农业; } \\
\text { (4)销售玉米、饲料以及旅游接待实现 } \\
\text { 增收。 }\end{array}$ & $\begin{array}{l}\text { (1)注重土地、生物、水、 } \\
\text { 景观等生态要素综合整 } \\
\text { 治; } \\
\text { (2)试点新型产权管理制 } \\
\text { 度,提高资产利用效率。 }\end{array}$ & $\begin{array}{l}\text { 自主经营能力不足、参 } \\
\text { 与热情不高、等靠要观 } \\
\text { 念普遍。 }\end{array}$ & $\begin{array}{l}\text { (1)变政府主导为政府引 } \\
\text { 导; } \\
\text { (2)加强政策宣讲、农民技 } \\
\text { 能培训和经营主体培育; } \\
\text { (3)逐步放宽乡村经营主 } \\
\text { 体资格限制。 }\end{array}$ \\
\hline $\begin{array}{l}\text { 多元综 } \\
\text { 合模式 }\end{array}$ & $\begin{array}{l}\text { 宝塔区 } \\
\mathrm{N} \text { 村 }\end{array}$ & $\begin{array}{l}\text { (1)治沟造地工程整治生态要素, 结合 } \\
\text { 红色资源营造生态与人文融合景观; } \\
\text { (2)依托“企业+新型主体+农户”体系 } \\
\text { 发展“种养+加工+旅游”特色产业; } \\
\text { (3)销售多种农副产品、发展生态和红 } \\
\text { 色旅游实现增收。 }\end{array}$ & $\begin{array}{l}\text { (1)采取多元经营策略, } \\
\text { 三产融合扩大规模; } \\
\text { (2)充分发挥品牌效应, } \\
\text { 拓宽产品销售渠道、吸 } \\
\text { 引国内外游客观光。 }\end{array}$ & $\begin{array}{l}\text { 不同集体所有权边界 } \\
\text { 存在纠纷, 产权界定不 } \\
\text { 清。 }\end{array}$ & $\begin{array}{l}\text { 加快完善乡村生态产权 } \\
\text { 制度,通过资源清查和边 } \\
\text { 界勘察明确产权主体的 } \\
\text { 权责归属, 确权登记实现 } \\
\text { 收益合理分配。 }\end{array}$ \\
\hline
\end{tabular}

作社, 村集体以土地资产入股参与经营, 通过统一 育苗、管理和收储的方式种植菌草, 引进加工技术 生产菌草饲料、生物菌肥，将部分饲料分发给农户， 并采用合作社垫资买牛、农户分年偿还的“借牛还 牛”方式发展养殖业, 利用农家肥、生物菌肥改善果 园土壤质量, 提高林果产量与品质。通过菌草饲 料、生物菌肥、活体肉牛和特色林果等产品销售发 展壮大集体经济, 按人股方式向农民分配利润, 并 以雇工的形式鼓励农民参与日常经营。 $\mathrm{D}$ 村通过 “坝地变基地、资金变股金、农民变股民”的三变改 革盘活乡村土地要素, 户均增收 6950 元, 带动 137 户贫困户脱贫致富。但该模式因产品滞销导致资 金短缺, 制约经营规模的进一步提升, 生态产品与 服务市场化环节受阻。因此, 政府应协助其与企 业、商超达成合作关系, 形成稳定的产品批发销售 市场, 借助电商平台、农展会等渠道, 积极拓展产品 零售市场。在增大政策扶持、财政投资和贷款优惠 力度的同时, 积极拓宽投资渠道, 吸纳更多社会资 本投人。

\section{2 休闲农业模式}

休闲农业模式是依托乡村土地、生物、水、景观 等生态要素构建的高效农业和生态旅游相融合的 产业体系。针对水土流失、沟道水毁和土地贫㾑问 题, 宝塔区 $\mathrm{S}$ 村稳步实施退耕还林还草工程, 促使植
被覆盖率保持在 $70 \%$ 以上,并逐步改善群落质量与 景观格局; 全面实施治沟造地工程,新增高标准农 田 2080 亩,并完善水利和灌溉等生产设施, 协调水 土要素关系; 逐步推行土壤复配工程, 加速耕地熟 化与质量提升,并打造营造荷塘、芦苇湖、玉米迷宫 等多处生态景观。新增耕地采取 “确权不确地”的 管理方式,并以租赁形成集中摆荒土地,实现生态 资产集中管理，根据其增值收益定期向农民分红， 为规模化、机械化产业发展奠定基础。政府主导成 立多个专业合作社, 并大力扶持其发展壮大,村集 体将耕地、林地和池塘等生态资产流转给合作社。 依托土地要素,形成“玉米+饲料油菜”的一年两季 轮作模式, 通过机械化种植和饲料油菜青贮推动种 植业与养殖业发展, 依托生物、水、景观等要素大力 发展生态旅游业, 吸引周边居民观光、采摘与垂 钧。S 村通过休闲农业模式发展既提高了农业种植 效益, 也拓宽了农民收人渠道, 农民人均纯收人提 高 1350 元,贫困人口减少 924 人。但政府“自上而 下”主导的产业模式, 缺乏乡村能人带动, 自主经营 能力不足、参与热情不高、“等靠要”观念普遍, 制约 了生态资产资本化的实现。亟需变政府主导为政 府引导, 加强政策宣讲、农民技能培训和经营主体 培育, 并逐步放宽乡村经营主体资格限制, 允许有 意愿的社会主体加人,统筹政府扶持与市场需求, 
激发乡村产业转型发展的内生动力。

\section{3 多元综合模式}

多元综合模式是按照三产业融合理念, 充分发 挥乡村生态要素和特色旅游资源优势建立的集高 效农业、休闲观光和红色旅游于一体的产业体系。 宝塔区 $\mathrm{N}$ 村位于延安著名红色景区内, 但长期以来 种植强度过大、耕作效率低下、排水设施老化, 导致 盐碱地、下湿地等中低产田广布, 水稻种植面积一 度不足 500 亩, 红色旅游也受到一定冲击。 $\mathrm{N}$ 村率 先实施治沟造地工程, 整治中低产田4832 亩, 通过 土体重构构建蒙金形耕作层,采用“拦一蓄一排”技 术解决农田排水灌溉难题, 利用土壤复配提升土壤 质量和熟化程度, 结合红色景观建设生态廊道、打 通生物通道、营造生态景观。政府牵头、多方投资 组建龙头企业,通过政府引导、企业带动或农民自 发等形式成立各类新型经营主体, 加强企业、新型 经营主体和农户的利益关联与经营协作, 依托各类 生态要素打造集高效农业、产品加工、特色旅游于 一体的红色小镇。 $\mathrm{N}$ 村充分发挥自身品牌效应, 利 用电商平台拓宽产品销售渠道, 吸引国内外游客旅 游观光。2017 年接待游客高达 130 万人次, 种植、养 殖和旅游收人分别为 640 万、 549 万和 2500 万元, 农 民人均收人增加 3468 元。但因国有农场与村集体 在新增耕地所有权边界上存在纠纷, 影响了土地流 转、规模经营和收益分配, 生态资源资产化无法顺 利实现。亟需加快完善乡村生态产权管理制度, 通 过资源清查和边界勘察明确产权主体与权责归属, 确权登记解决产权纠纷, 实现资源有效利用和收益 合理分配。

\section{5 结论、政策建议与展望}

\section{1 结论}

本文基于乡村地域系统、地理工程、生态价值 理论和科斯产权定理, 系统剖析了黄土丘陵沟壑区 乡村生态产业化的内在机理, 并结合延安市典型实 践, 提炼出适宜区域推广的模式及其可持续路径。 主要结论有:

（1）黄土丘陵沟壑区乡村生态产业化应着眼于 乡村地域系统要素、结构和功能, 遵循自然演化规 律、系统耦合机理和价值转化原则, 进行技术性整 治、社会化生产和市场化经营, 通过生态资源培育、
生态资源资产化、生态资产资本化、生态产品与服 务市场化等过程环节的有序开展,实现生态资源提 质增效, 协调乡村生态保护与产业发展之间的矛 盾, 为城乡生态和资金要素的流通提供有效渠道, 提升区域乡村可持续发展能力和竞争力。

(2)延安市地处黄土丘陵沟壑区的核心区域, 全面实施退耕还林(草)工程和治沟造地工程, 变退 化或不可持续生态要素为优质生态资源。部分乡 村通过产权划分、产业融合和市场运作，开展了“资 源变资产、资产变资本、资本变资金”的生态产业化 实践,逐步形成了高效种养、休闲农业和多元综合 3 种典型模式。但区域生态产业化处于起步探索阶 段,经营规模不大、自主能力不足和产权界定不清 等造成上述产业模式在不同过程环节中受阻。

\section{2 政策建议}

黄土丘陵沟壑区适时推进乡村生态产业化,既 有利于巩固生态建设成果, 也有助于产业发展与农 民增收。但乡村是一个复杂的地域系统, 为促使生 态产业化朝规模化、专业化和集约化方向发展, 本 文提出以下政策建议:

(1)加快推进各类地理工程实施, 并注重工程 后期成效监督及其维护力度。具体而言,退耕还林 (草)工程应兼顾植被数量和质量的同步提升, 对植 被群落进行适度更新优化, 减少植被恢复对土壤水 资源影响; 巩固提升治沟造地工程的现有成果, 加 强对坝系稳定、土地沉降、边坡滑塌等次生灾害的 监测。

(2)健全乡村生态产权管理机制, 明确产权归 属与权属关系, 减少产权纠纷与资源闲置。培育良 好环境吸引乡村能人返乡创业, 逐步放宽限制吸纳 社会力量参与产业经营,保障农民权益吸纳更多农 民参加生产管理, 激活产业发展的内生活力和动 力。同时, 拓展多元融资渠道, 搭建与企业、高校、 科研机构合作平台,解决资金、技术短缺难题。

(3)县级农业部门组织相关专家或第三方开展 生态产业化评估, 以村域为单位, 通过生态资源储 量、资源确权率、经营主体能力、集体经济产值和农 民人均收人及其增长率等指标反映其水平。对发 展水平较好的村域给予资金、政策、项目等支持, 支 撑、鼓励其规模的进一步提升。 


\section{3 展望}

生态产业化将有效推动乡村空间重构、组织重 建、产业重塑,促使生态、生产、生态和文化功能的 提升, 推动乡村地域系统耦合和可持续发展。本文 以黄土丘陵沟壑区为例, 结合延安市典型案例从理 论层面对乡村生态产业化进行了初步解析, 但推动 乡村生态产业化落实落地, 未来应加强以下方面的 研究, 为实现生态建设、精准扶贫与乡村振兴的有 效衔接提供科学依据。

(1) 加强地理工程技术研发, 提出乡村生态资 源综合整治的专项规划、技术方案和规范指南, 为 不同区域生态资源培育提供技术指导。同时,基于 区域自然分异和产业比较优势, 开展相关试验示 范, 创新生产经营方式, 为资源利用效率提升和收 益增加提供基础。

(2)结合中国国情, 探索构建生态价值评估体 系与生态产权管理制度, 并根据市场需求逐步完善 生态市场交易机制, 重点研究形成跨区域的生态补 偿体系和标准, 为生态产业化发展提供产权保障和 资金支持。

(3)构建乡村生态产业化发展评估体系与模型 方式, 选取典型案例区, 通过长期的定点观测, 深人 剖析生态产业化对乡村地域系统耦合的影响机制， 促进乡村人地协调与可持续发展。

\section{参考文献(References):}

[1] 刘彦随, 严镔, 王艳飞. 新时期中国城乡发展的主要问题与转型 对策[J]. 经济地理, 2016, 36(7): 1-8. [Liu Y S, Yan B, Wang Y F. Urban- rural development problems and transformation countermeasures in the new period in China[J]. Economic Geography, 2016, 36(7): 1-8.]

[2] 高吉喜, 李慧敏, 田美荣. 生态资产资本化概念及意义解析 [J]. 生态与农村环境学报, 2016, 32(1): 41-46. [Gao J X, Li H M, Tian M R. Concept and significance of ecological assets capitalization[J]. Journal of Ecology and Rural Environment, 2016, 32(1): 41-46.]

[3] 黎元生. 生态产业化经营与生态产品价值实现[J]. 中国特色社 会主义研究, 2018, (4): 84-90. [Li Y S. Industrialized operation of ecology and realizing the value of ecological goods[J]. Studies on Socialism with Chinese Characteristics, 2018, (4): 84-90.]

[4] Anderson L T, Leal D R. Free Market Environmentalism[M]. Boulder: Westview Press, 1991.
[5] 刘彦随. 中国新时代城乡融合与乡村振兴[J]. 地理学报, 2018, 73(4): 637-650. [Liu Y S. Research on the urban-rural integration and rural revitalization in the new era in China[J]. Acta Geographica Sinica, 2018, 73(4): 637-650.]

[6]陈秧分, 王国刚, 孙炜琳. 乡村振兴战略中的农业地位与农业发 展[J]. 农业经济问题, 2018, (1): 20-26. [Chen Y F, Wang G G, Sun W L. Agricultural status and agricultural development in the rural revitalization strategy[J]. Issues in Agricultural Economy, 2018, (1): 20-26.]

[7] 庄晋财, 王春燕. 复合系统视角的美丽乡村可持续发展研究: 广 西恭城瑶族自治县红岩村的案例[J]. 农业经济问题, 2016, 37 (6): 9-17. [Zhuang J C, Wang C Y. Research on the sustainable development of beautiful countryside through compound system perspective: Case study of Hongyan Village in Guangxi Province [J]. Issues in Agricultural Economy, 2016, 37(6): 9-17.]

[8] 张文明, 张孝德. 生态资源资本化: 一个框架性阐述 [J]. 改革, 2019, (1): 122-131. [Zhang W M, Zhang X D. The capitalization of ecological resources: An explanatory framework[J]. Reform, 2019, (1): 122-131.]

[ 9] Fenech A, Foster J, Hamilton K, et al. Natural capital in ecology and economics: An overview[J]. Environmental Monitoring and Assessment, 2003, 86(1): 3-17.

[10] 严立冬, 陈光炬, 刘加林, 等. 生态资本构成要素解析: 基于生态 经济学文献的综述 [J]. 中南财经政法大学学报, 2010, 53(5): 39. [Yan L D, Chen G J, Liu J L, et al. On constituents of ecological capital: Based on ecological economics literature[J]. Journal of Zhongnan University of Economics and Law, 2010, 53(5): 3-9.]

[11] 谢高地, 曹淑艳. 发展转型的生态经济化和经济生态化过程[J] 资源科学, 2010, 32(4): 782-789. [Xie G D, Cao S Y. Ecological economization and economic ecologizaiton in succession progress of development[J]. Resources Science, 2010, 32(4): 782-789.]

[12] 刘彦随, 靳晓燕, 胡业翠. 黄土丘陵沟壑区农村特色生态经济模 式探讨: 以陕西绥德县为例 [J]. 自然资源学报, 2006, 21(5): 738-745. [Liu Y S, Jin X Y, Hu Y C. Study on the pattern of rural distinctive eco-economy based on land resources: A case study of Suide County in Loess Hilly areas[J]. Journal of Natural Resources, 2006, 21(5): 738-745.]

[13] Ciaian P. Land market imperfections and agricultural policy impacts in the new EU member states: A partial equilibrium analysis [J]. American Journal of Agricultural Economics, 2006, 88(4): 799-815.

[14] 严立冬, 屈志光, 方时姣. 水资源生态资本化运营探讨[J]. 中国 人口·资源与环境, 2011, 21(12): 81-84. [Yan L D, Qu Z G, Fang $\mathrm{S}$ J. Discussion on eco-capital operation of water resources[J]. China Population, Resources and Environment, 2011, 21(12): 81-84.]

[15] 张英, 成杰民, 王晓凤, 等. 生态产品市场化实现路径及二元价 格体系 [J]. 中国人口・资源与环境, 2016, 26(3): 171-176 
[Zhang Y, Cheng J M, Wang X F, et al. Marketization path of ecological products and its buy-sell dual structure price system[J]. China Population, Resources and Environment, 2016, 26(3): 171176.]

[16] Liu Y S, Li Y H. Revitalize the world's countryside[J]. Nature, 2017, 548(7667): 275-277.

[17] Lü Y H, Fu B J, Feng X M, et al. A policy-driven large scale ecological restoration: Quantifying ecosystem services changes in the Loess Plateau of China[J]. Plos One, 2012, 7(2): e31782.

[18] Wang S, Fu B J, Piao S L, et al. Reduced sediment transport in the Yellow River due to anthropogenic changes[J]. Nature Geoscience, 2016, 9(1): 38-42.

[19] Chen Y P, Wang K B, Lin Y S, et al. Balancing green and grain trade[J]. Nature Geoscience, 2015, 8: 739-741.

[20] Cao S X, Chen L, Yu X X. Impact of China's Grain for Green Project on the landscape of vulnerable arid and semi-arid agricultural regions: A case study in Northern Shaanxi Province[J]. Journal of Applied Ecology, 2009, 46(3): 536-543.

[21] 刘彦随, 陈宗峰, 李裕瑞, 等. 黄土丘陵沟壑区饲料油菜种植试 验及其产业化前景: 以延安治沟造地典型项目区为例 $[\mathrm{J}]$. 自然 资源学报, 2017, 32(12): 2065-2074. [Liu Y S, Chen Z F, Li Y R, et al. The planting technology and industrial development prospects of forage rape in the Loess Hilly area: A case study of newlyincreased cultivated land through gully land consolidation in Yan' an, Shaanxi Province[J]. Journal of Natural Resources, 2017, 32 (12): 2065-2074.]

[22] Mamo G, Sjaastad E, Vedeld P L. Economic dependence on forest resources: A case from Dendi District, Ethiopia[J]. Forest Policy \& Economics, 2007, 9(8): 916-927.

[23] Holmes J. Impulses towards a multifunctional transition in rural Australia: Gaps in the research agenda[J]. Journal of Rural Studies, 2006, 22(2): 142-160.

[24] 张利国, 王占岐, 魏超, 等. 基于村域多功能视角的乡村振兴策 略: 以鄂西郧阳山区为例 [J]. 资源科学, 2019, 41(9): 17031713. [Zhang L G, Wang Z Q, Wei C, et al. Rural revitalization strategy based on the perspective of rural multifunction: A case of the mountainous areas in Yunyang District of Shiyan City, western Hubei Province[J]. Resources Science, 2019, 41(9): 1703-1713.]

[25] 陈长. 省域生态产业化与产业生态化协同发展理论、实证: 以贵 州为例[J]. 贵州社会科学, 2019, (8): 122-130. [Chen C. Theoretical and empirical study on coordinated development of provincial eco-industrialization and industrial ecology: A case study on Guizhou[J]. Guizhou Social Sciences, 2019, (8): 122-130.]

[26] 陈洪波. “产业生态化和生态产业化”的逻辑内涵与实现途径
[J]. 生态经济, 2018, 34(10): 209-213. [Chen H B. Logical connotation and implementation way of "industrial ecologicalization and ecological industrialization” [J]. Ecological Economy, 2018, 34 (10): 209-213.]

[27] 唐建荣. 生态经济学[M]. 北京: 化学工业出版社, 2005. [Tang J R. Ecological Economic[M]. Beijing: Chemistry Industry Press, 2005.]

[28] Liu Y S. Introduction to land use and rural sustainability in China [J]. Land Use Policy, 2018, 74: 1-4.

[29] Liu Y S, Wang Y S. Rural land engineering and poverty alleviation: Lessons from typical regions in China[J]. Journal of Geographical Sciences, 2019, 29(5): 643-657.

[30] 罗必良. 科斯定理: 反思与拓展: 兼论中国农地流转制度改革与 选择[J]. 经济研究, 2017, (11): 178-193. [Luo B L. Rethinking and extension of the Coase Theorem: Reform and choice of land circulation institutions in rural China[J]. Economic Research Journal, 2017, (11): 178-193.]

[31] 李文华, 刘某承, 闵庆文. 中国生态农业的发展与展望 $[\mathrm{J}]$. 资源 科学, 2010, 32(6): 1015-1021. [Li W H, Liu M C, Min Q W. Progress and perspectives of China's ecological agriculture[J]. Resources Science, 2010, 32(6): 1051-1021.]

[32] 刘彦随, 李裕瑞. 黄土丘陵沟壑区沟道土地整治工程原理与设 计技术[J]. 农业工程学报, 2017, 33(10): 1-9. [Liu Y S, Li Y R Engineering philosophy and design scheme of gully land consolidation in Loess Plateau[J]. Transactions of the Chinese Society of Agricultural Engineering, 2017, 33(10): 1-9.]

[33] 谢高地. 生态资产评价: 存量、质量与价值[J]. 环境保护, 2017, 45(11): 18-22. [Xie G D. Ecological asset evaluation: Stock, quality and value[J]. Environmental Protection, 2017, 45(11): 18-22.]

[34] 白杨, 李晖, 王晓媛, 等. 云南省生态资产与生态系统生产总值 核算体系研究[J]. 自然资源学报, 2017, 32(7): 1100-1112. [Bai Y, Li H, Wang X Y, et al. Evaluating natural resource assets and gross ecosystem products using ecological accounting system: A case study in Yunnan Province[J]. Journal of Natural Resources, 2017, 32(7): 1100-1112.]

[35] 刘庆宝, 蔵凯波. 如何实现生态产权的合理界定[J]. 环境保护, 2013, 41(13): 47-48. [Liu Q B, Zang K B. How to realize the reasonable definition of ecological property rights[J]. Environmental Protection, 2013, 41(13): 47-48.]

[36] 曾贤刚, 虞慧怡, 谢芳. 生态产品的概念、分类及其市场化供给 机制[J]. 中国人口・资源与环境, 2014, 24(7): 12-17. [Zeng X G, Yu H Y, Xie F. Concept, classification and market supply mechanism of ecological products[J]. China Population, Resources and Environment, 2014, 24(7): 12-17.] 


\title{
Mechanism and typical patterns of rural ecological industrialization in the Loess Hilly-Gully region of China
}

\author{
ZHANG Xuanchang ${ }^{1,2,3}$, LIU Yansui ${ }^{1,2,3}$, LI Yurui ${ }^{1,2}$, GUO Yuanzhi' ${ }^{1,2}$, CAO Zhi ${ }^{1,2}$ \\ (1. Institute of Geographic Sciences and Natural Resources Research, CAS, Beijing 100101, China; 2. Key Laboratory of \\ Regional Sustainable Development Modeling, CAS, Beijing 100101, China; 3. College of Resources and Environment, \\ University of Chinese Academy of Sciences, Beijing 100049, China)
}

\begin{abstract}
Rural ecological industrialization is an important approach to promote the healthy interaction of ecological construction and industrial development, which could advance the sustainable development of regional rural systems in the new era. China' Loess Hilly-Gully region is a typical geomorphic unit of the Loess Plateau locating in the middle reaches of the Yellow river, regional eco-environment was fragile and conflict of the rural human-land relationship was prominent. The Grain-for-Green Project significantly improved the ecological functions, but rural issues were still prominent, including weak agricultural foundation, the increase of water-soil constrains, and relatively low production efficiency. Therefore, it is urgent to promote ecological industrialization for improving rural production and living functions. From the perspective of ecological resource value proliferation, this study analyzed the mechanism of rural ecological industrialization in the Loess Hilly-Gully region. Meanwhile, the typical patterns and its sustainable approaches were explored according to the existing practices after the Gully Land Consolidation Project in Yan' an City. The results indicate that: (1) Rural ecological industrialization should be based on regional rural system, and follow the law of evolution, the mechanism of system coupling, and the principle of value transformation. The key processes are as follows: cultivation of ecological resources by geographical engineering, asset management of ecological resources by establishing ecological property rights system, capitalization of ecological assets through asset circulation, stakeholder development and industrial integration, and the marketization of ecological products and services through improving the ecological market trading mechanism. (2) Some villages in Yan' an City realized ecological resources cultivation relying on the Gully Land Consolidation Project, explored the path of resources translating to assets, then turning to capitals and finally converting to funds. Three typical patterns of ecological industrialization have gradually formed: efficient planting-breeding, leisure agriculture, and integration of multiple factors. (3) In the future, weaknesses in the industrialization process could be overcome by geographical engineering effect maintenance, property rights system development, rural talents cultivation, social forces participation, and dynamic evaluation mechanism development. The above approaches would effectively advance the organic integration of rural production, living, and ecological functions, and achieve the aims of rural revitalization of thriving businesses, pleasant living environments, and prosperity.
\end{abstract}

Key words: ecological industrialization; regional rural system; geographical engineering; rural revitalization; the Loess Hilly-Gully region; Yan' an City 